Article

\title{
Diversity Policing-Policing Diversity: Performing Ethnicity in Police and Private-Security Work in Sweden
}

\author{
Cecilia Hansen Löfstrand * and Sara Uhnoo \\ Department of Sociology and Work Science, University of Gothenburg, Sprängkullsgatan 25, 40530 Gothenburg, \\ Sweden; E-Mails: cecilia.lofstrand@socav.gu.se (C.H.L.), sara.uhnoo@socav.gu.se (S.U.); Tel.: +46-31-786-4766; \\ Fax: +46-31-786-4764 \\ * Corresponding author
}

Submitted: 7 April 2014 | In Revised Form: 19 June 2014 | Accepted: 23 June 2014 | Published: 17 September 2014

\begin{abstract}
This article draws upon two separate studies on policing in Sweden, both investigating "ethnic diversity" as a discourse and a practice in the performance of policing functions: one interview study with minority police officers from a county police authority and one ethnographic study of private security officers. To examine how "diversity policing" and the "policing of diversity" are performed by policing actors, their strategic reliance on an ethnically diverse workforce is examined. The official discourse in both contexts stressed "diversity policing" as a valuable resource for the effective execution of policing tasks and the legitimation of policing functions. There was, however, also another, more unofficial discourse on ethnicity that heavily influenced the policing agents' day-to-day work. The resulting practice of "policing diversity" involved situated activities on the ground through which "foreign elements" in the population were policed using ethnicized stereotypes. Diversity in the policing workforce promoted the practice of ethnic matching, which, ironically, in turn perpetuated stereotypical thinking about Swedish "others". A conceptual framework is developed for understanding the policing strategies involved and the disjuncture found between the widely accepted rationalities for recruiting an ethnically diverse workforce and the realities for that workforce's effective deployment at the street level.
\end{abstract}

\section{Keywords}

diversity policing; ethnic matching; policing; policing diversity; stereotypes

Issue

This article is part of the special issue "Policing Ethnicity: Between the Rhetoric of Inclusion and the Practices and Policies of Exclusion", edited by Professor Abby Peterson (University of Gothenburg, Sweden) and Professor Malin Åkerström (University of Lund, Sweden).

(C) 2014 by the authors; licensee Cogitatio (Lisbon, Portugal). This article is licensed under a Creative Commons Attribution 4.0 International License (CC BY).

\section{Introduction}

Drawing on two separate studies on policing in Sweden, this article examines how "ethnic diversity" is used by two different kinds of policing actors in the performance of their policing functions, as both a discourse and a practical strategy influencing the daily work of public police officers and private security providers. We look at the discourses on diversity among policing agents as something providing the norms regulating their thinking, interpreting, understanding, and acting in society (de los Reyes, 2000). More specifically, what we explore are the phenomena of diversity policing and, especially, policing diversity among Swedish policing agents as two increasingly important instances of "doing ethnicity".

The term 'diversity policing' refers to the efforts by both the police and security service operators to recruit and retain a heterogenouos, or ethnically diverse, workforce. One underlying rationale in these efforts in Sweden has been the need to better mirror the heterogeneity of the country's general population. This has 
been seen as necessary for the policing agents' ability to legitimate their actions, activities, and purposes, provide higher-quality services, and perform their policing tasks more effectively.

The phenomenon of 'policing diversity' refers to the utilization of an ethnically diverse workforce to facilitate police and private security officers' concrete everyday work in an ethnically diverse public. Previous research has shown how police work (Bowling \& Phillips, 2007; Rowe, 2002; Young, 1994), the "police gaze" (Finstad, 2000), and the work and "gaze" of private security providers (Gabbidon, 2003; Hutchinson \& O'Connor, 2005; McCahill, 2002) all entail the practice of policing stereotypes (Holmberg, 2003). In it, the attention of policing agents is directed at individuals perceived as standing out from the crowd, resulting in, for instance, those of a certain skin colour, or those driving a certain type of vehicle, becoming targeted more often or more readily than others. Such discriminatory profiling by policing agents typically affects young men from minority backgrounds (e.g., Antonopoulos, 2003; Kempa \& Singh, 2008; O'Dougherty, 2006; Sollund, 2006; Wakefield, 2003). In the Swedish context, one has witnessed the ethnicized stereotyping of the construct "foreigner" and the application of the term to set apart those perceived as belonging to ethnic minorities. As will be shown, the study participants not only policed stereotypes, but also themselves made use of ethnicized stereotypes when performing work tasks, policing through stereotypes. In this actual, concrete policing work, however, 'ethnicity' as a notion was transformed, becoming a question of skin colour, general appearance, and language proficiency, with the new conceptualization then put to use to aid one's work in interactions with the public.

In looking at the situated activities that the practice of policing diversity involved on the ground-the policing of "foreign" elements in the population through the use of ethnicized stereotypes-the main questions guiding our investigation were: Why, how, and with what consequences is the strategy of policing through stereotypes made use of by public and private policing agents? What kind of overall impact is the emergence of the practice of diversity policing and policing diversity likely to have from the perspective of societal inclusion and exclusion? In pursuing some answers to these questions below, our objective is to contribute to an improved conceptual understanding of, on the one hand, these policing strategies as such and, on the other hand, the disjuncture prevailing between the widely accepted rationalities for diversity recruiting in Sweden and the realities for the effective deployment of an ethnically diverse workforce on the ground in its interactions with the public. In doing so, we focus on features and characteristics that are common to the policing efforts of both the public police and private security providers rather than on what separates them. In a modern multi-ethnic society, this focus usefully narrows down on discourses on ethnic diversity among policing agents and the question of how the norms that these discourses provide for the policing agents' thinking and interpreting in concrete work situations are translated into situated activities resorted to on the ground.

\section{Policing through Stereotypes: Towards an Analysis of Policing in a Multi-Ethnic Society}

For the purposes of this article, we define 'policing' as the exercise of a particular form of social control encompassing purposeful activities to maintain security within a given social order (cf. Button, 2002; Crawford, 2008; Loader, 2000). The distinction made in the literature between private and public policing, where the former stands for the policing activities of private security companies and the latter for the activities of the public police authority, has been criticized as an overly simplified dichotomy not particularly useful for analytical purposes (Bayley \& Shearing, 2001; Crawford \& Lister, 2006; Hutchinson \& O'Connor, 2005; Kempa et al., 1999; Rigakos, 2002; Stenning, 2009; Williams, 2008). In this article, we adopt this criticism as a point of departure in our effort to focus more on general commonalities between different modes of policing, regardless of the type of organization (public or private), power, and authority and the kind of regulatory framework involved. In particular, four such commonalities can be identified that, while of interest in themselves, pose specific challenges to both public police and private security actors engaged in policing work in modern multi-ethnic socities and thus form the background of our analysis presented in this article.

First of all, the importance of diversity in the workforce has been stressed for both types of policing organizations. In consequence, just as in many places elsewhere in Europe (see, e.g., Jones \& Williams, 2013; van Ewijk, 2011), the Swedish police authorities have in recent years introduced various programmes to encourage ethnic minority officers to apply to the police academies (see, e.g., Gunnmo, 2004; Lander, 2013). Within the country's private security industry, individual companies have recently begun to actively promote diversity in the workforce, as part of a branding strategy to attract both customers and potential employees. These efforts have parallelled a trend where public entities and institutions in the country are increasingly contracting private security companies, which thereby come to more and more perform public functions.

Secondly, despite the efforts invested in promoting ethnic diversity within the two types of policing organizations in Sweden investigated here, the number of those foreign-born in the country's police force and private security services has not increased in proportion to population changes in society. Currently, no 
more than three per cent of all the police officers and 13 per cent of the private security officers employed in the country are foreign-born. The proportion of those in the country's total population with an 'ethnic minority background' has continued to go up, being currently at 21 per cent (Statistics Sweden, 2012a, 2013). ${ }^{1}$ In major urban and metropolitan areas, the difference is significantly larger still: in the metropolitan municipality where the two studies reported on in this article were conducted, for example, the share of ethnic minority residents at the time of the study was 32 per cent. The two types of policing organizations in Sweden investigated here, in other words, face an increasing need to have their workforce composition better mirror the increasing ethnic diversity of the population.

Thirdly, the specific mode of policing diversity discussed in this article was mainly made use of in relation to members of the public encountered in, or otherwise associated with, the socio-economically and ethnically segregated suburbs of the city. Among the inhabitants of these suburbs, the share of those coming from an ethnic minority background ranged from 55 to 71 per cent (Statistics Sweden, 2012b). In the municipality, these suburbs were perceived by the broader public as being heavily "non-white" (Werner, 2014), "dangerous", and infested with crime (cf. Hallsworth, 2006; Sernhede, 2006, 2009). Policing agents, for their part, commonly viewed them as "resentful environments" (Hansen Löfstrand, 2013b; cf. Pettersson, 2013). In such environments, those policing the streets typically expect, try to avoid, and have to manage being subjected to accusations of discrimination, while at the same time needing to establish and maintain legitimacy for their actions.

Lastly, what the different policing actors in society have in common is their orientation towards preventing crime and other illegitimate behaviours through risk management. This entails focus on the management of individuals and groups perceived as more likely than others to threaten or disturb the social order and to commit crime (see Garland, 1996; Johnston, 1999; Johnston \& Shearing, 2003; Loader, 2000). This kind of policing is premissed on stereotypical generalizations, in turn based on experience, perception, and beliefs

\footnotetext{
1 Those with an 'ethnic minority background' in the official Swedish statistics are defined as individuals who were either themselves born outside of Sweden or have both parents born abroad (Statistics Sweden, 2012b). According to the Swedish Police Authority's own statistics, approximately 6 per cent of the police officers working in Sweden currently have an 'ethnic minority background' (The Swedish National Police Board, 2014), however, only three per cent of the police officers working in Sweden are themselves born outside of Sweden. Among all private security officers working in Sweden 13 per cent are born abroad. There is, however, no data available on the share of private security officers with an 'ethnic minority background' currently working in the country.
}

regarding risk groups (Feeley \& Simon, 1992; Finstad, 2000; Hydén \& Lundberg, 2004; Rose, 2000; Zedner, 2003, pp. 166-167).

\section{Materials and Methods}

The research reported on in this article drew on two separate studies of policing in Sweden: an interview study with minority police officers and an ethnographic study of the work of private security officers. The interviews with the police workers investigated the situation of ethnic minority employees working for a county police authority (Uhnoo \& Peterson, 2011). Interviews were carried out with 21 current and former employees of the Swedish Police who identified their background as "foreign", nine of whom were women and 11 men. Seven of the study participants worked for the police as civilian staff and 13 as uniformed officers. In addition, one woman participant joined the project at a later stage. The "foreignness" for them designated anything from having been born outside of Sweden to having been adopted from abroad by Swedish-born parents.

In the ethnographic study on the work of private security officers, the data was collected through fieldwork, which entailed accompanying security officers engaged in their daily work. The private security officers were both female and male, and they came from both ethnically "Swedish" and "non-Swedish" backgrounds. Observations and informal field-based interviews were carried out on 27 different occasions, for four to 13 contiguous hours each time (most commonly seven). In addition, one formal interview was conducted with the managing director of the security company in question (Hansen Löfstrand, 2013a, 2013b). The security officers' were only allowed to use force in self-defence, and were commonly carrying nothing more than a baton and handcuffs on duty. Their work of patrolling frequently entailed interactions with members of the general public encountered on the sites within their patrol area.

\section{Diversity Policing: The Official Discourse}

The current public rhetoric and politics in Sweden stress "difference" and "diversity" in society as something worth striving for: they are held to constitute an asset especially in a variety of employment-related contexts (de los Reyes \& Martinsson, 2005, p. 9). This forms an important discursive environment for both the police authorities and private security service providers in the country. In it, however, diversity is viewed in essentially ethnic terms and directly linked to qualities such as "foreignness" or "non-Swedishness." To recruit a diverse workforce accordingly means recruiting individuals from ethnic backgrounds other than the native "Swedish" one, based, in particular, on what seems to be a widespread notion in Sweden of Swe- 
dishness, as something reflected in one's appearance (see, e.g., Mattson, 2005). According to some research, being "Swedish" tends today to increasingly imply having a blond hair, blue eyes, and a white skin, rather than referring to particular customs, clothing, or language (Werner, 2014).

In the Swedish Police Service, diversity policing was initiated in a top-down fashion, following the introduction of national policies that provided for the implementation and management of diversity in all governmental organizations. Within the police authority, the terms of the official discourse on diversity were set in a national policy and action plan, which defined the advantages that diversity was seen to offer as follows:

Diversity shall be an integrated and natural part of the Swedish Police's operations and shall contribute to a more representative, efficient and attractive organization...Diversity shall provide the Swedish Police improved prerequisites to solve their tasks. Interactive differences shall be an asset to the Swedish Police. (The Swedish National Police Board, 2010, p. 3)

Diversity was thus proposed to constitute a resource that would clearly contribute to the efficiency and effectiveness of the police in carrying out its mandate. In addition, the symbolic importance of ethnic diversity in the workforce was stressed at policy level: "The Swedish Police must clearly show what a democratic society stands for. This means that we shall...be good role models in the multicultural society" and "representative" as an organization (The Swedish National Police Board, 2010 , p. 3). A more diverse workforce, in other words, would result in an appearance of greater representativeness and legitimacy (cf. Ward, 2006, p. 69). Nothing, however, was stated about what the valuable resource that the incorporation of ethnic-minority officers into the police force offered consisted of, exactly, or about how this resource should, or could, be made use of in the police's day-to-day work (see also Lander, 2013).

The private security company included in this study, on the other hand, stated diversity policing to form an important part of a successful business concept for it: it was something that would allow the company to deliver better service to its customers-indeed, better than that of its competitors. Furthermore, both those representing the company's management and its employees working on the street talked about the "diversity of ethnicities" in their company's workforce as a source of "pride". In its promotional material, the company claimed to value diversity highly, stating that it strove to serve as "a role model and an inspiration" for other actors in the country's private-sector security industry. As one of its security officers explained it, "the point is to provide good services, treat the public nicely, and thus get a good reputation." This image projected by the company was, furthermore, linked to its strategy of employing security officers from several different ethnic backgrounds representing a variety of nationalitites, "looks", and mother tongues. In an interview, the firm's managing director depicted the company as a rare example within the industry, as an actor "thinking a bit more broadly" than its competitors in the country's private security sector: "We have something we call the multicultural Sweden, and that's how we recruit." Recruiting an ethnically diverse workforce was one way for the company to show its conscience, its corporate social responsibility.

Thus, in both the county police authority and the private security company in this study, ethnic diversity in the workforce was deemed important from the point of view of one's ability, as a policing actor, to mirror the ethnical heterogeneity of the general population in one's own organization-something that, in turn, was seen as necessary for one's ability to claim, achieve, and maintain legitimacy in the context of a modern multi-ethnic and democratic society. Just like the public police, also private security providers need to achieve and maintain a certain legitimacy in the eyes of the public (e.g., Hansen Löfstrand, 2013b; Thumala, Goold, \& Loader, 2011). One way of gaining the needed legitimacy is then to appeal to public values generally taken to stand for something positive in and for the society (such as a sense of social responsibility and diversity). Furthermore, both the management-level personnel and individual security officers working for that company compared their work to the diversity policy of the police authority, which may be interpreted as an instance of "symbolic borrowing", an attempt to secure legitimacy by associating oneself with the public police with the hope of appearing as as competent and respectable as it (cf. Thumala, Goold, \& Loader, 2011, p. 294).

Diversity within the workforce can promote the goal to build and maintain a certain legitimacy in two ways: on the one hand, it, in at least potentially increasing fairness and justice in society by promoting equality and non-discrimination in the treatment of its members (policing becomes more fair and egalitarian when minorities police minorities), can have substantive outcomes that appeal to established public values, while, on the other hand, it may serve as a symbolic tool that helps to promote a mere appearance of legitimacy (cf. Ward, 2006, p. 69). The notion that diversity promotes fairness and justice is based on an assumption that policing agents from ethnic minority backgrounds bring unique skills and perspectives to policing organizations, resources that can help offset their colleagues' counterproductive biases and tendencies such as to develop and use ethnic profiles. Irrespective of any such actual impact that ethnic workforce diversity might have on the work and situated actions of the policing agents on the street, however, such diversity also "bolsters the perceived legitimacy" of the organization 
and its purposes and actions (Ward, 2006, p. 70; emphasis added).

According to the public police and private security officers included in this study, diversity policing, which here meant mostly diversity recruiting, would result in both a substantial increase of fairness and justice and serve a symbolic function in lending the work of the policing agents the appearance of legitimacy, credibility, and respectability in the eyes of the public. In addition, diversity policing was claimed to contribute to more effective work and more efficient organizations. All of these claims, however, are left unsubstantiated and vague; how diversity policing can supposedly achieve all this is nowhere explained or even touched upon. In the section that follows, we therefore examine the concrete ways in which ethnic workforce diversity is drawn upon in actual policing practice in and through the situated activitites and interactions in which police and private security officers become involved as part of their day-to-day work, to clarify how, in the concrete thinking of those performing the policing activities, diversity policing was going to contribute to more efficient organizations, more effective policing work, and more (perceived or real) legitimacy for the policing agents.

\section{Policing Diversity: The Unofficial Discourse and the Practice of Policing through Stereotypes}

The alternative discourse on ethnic diversity that could be seen as available to the police and security officers in this study, rather more unofficial in nature, depicted workforce diversity as something strategically desireable and highly useful, motivated by the need, in especial, to facilitate one's work on the streets and make it produce better results. A closer look at how ethnic diversity in the workforce was put to work, strategically, in the actual practice of police and private security officers on the street through organizational and situational deployment of techniques like ethnic matching reveals that it was, in fact, this alternative, more unofficial discourse that provided the policing agents' norms for accepted thinking, interpreting, understanding, and indeed acting in the situations they encountered in the course of their everyday work. Depicting "foreigners" as a category overrepresented among the "criminals" in the country, it called for policing agents to incorporate these elements in their workforce composition and that way perform their policing tasks more effectively and gain better access to the "criminal environments" in their concern.

The implicit assumption behind practices like ethnic matching is that those sharing certain "ethnic markers" such as physical appearance (skin colour, bodily conduct, emotive expressions, etc.) are more closely related and thus understand one another and interact better and more readily than those who differ from one another in these respects. All this then makes ethnic matching appear as a rational choice in policing: police employees or security staff coming from ethnicminority ("foreign") backgrounds, the thinking suggests, should then be the ones to police ethnic minorities in the public, producing as they would better outcomes than their ethnically "Swedish" colleagues attempting the same (cf. Hansen Löfstrand, 2013b; Wästerfors \& Burcar, 2014). Underlying this distinction between "foreigners" and "Swedes" in the workforce of the policing agents, just as in the population at large, is a specific notion of "Swedishness", one that is linked to appearance: in it, a "Swedish" appearance is "equated with being blond and having blue eyes, which involves a direct and clear link between Swedishness and whiteness" (Mattson, 2005, p. 150). By extension, dark skin, hair, and eyes are then taken to signify "foreignness" implying deviation and difference (Mattson, 2005, pp. 151-152).

\subsection{Organizational Ethnic Matching}

The policing of diversity, or the way in which an ethnically diverse workforce is made use of in the concrete everyday work of police and private security officers through the application of techniques like ethnic matching, can be carried out at both an organizational and a situational level. By 'organizational ethnic matching', we refer to the practice of planning and staffing entire sections or units of a policing organization or particular work tasks or assignments in such a way as to ensure ethnic diversity in the staff dedicated to these. In the organizations we studied, this was done to facilitate the strategic use of the "Swedishness" or "foreignness" of the employees in their actual performance of policing tasks in concrete situated actions and interactions. Planning and staffing sections and units as well as individual work tasks or special assignment to ensure ethnic diversity in them is what then enabled-but is distinct from-situational ethnic matching.

Organizational ethnic matching in the county police authority in this study took a somewhat different form than in the security company investigated, mainly as a consequence of differences in the organizational size and tasks between the two. The mission of the Swedish Police is a broad one and is not limited to simply reducing crime; it also involves the provision of certain services to the public and the protection of public safety more broadly. According to the police officers interviewed for this study, for some functions of the country's overall police service-mainly the border police (controlling whether those travelling into the country have valid travel documents and may stay in it, and looking for wanted persons), the juvenile police (dealing especially with youths), the passport offices, and covert policing (e.g., the narcotics division)-special efforts had been made to recruit from ethnic minorities 
and staff the services so as to ensure, or at least enable, ethnic matching on the ground. Staff representing the country's ethnic minorities were, according to the interviewed officers, in these sections considered as a particularly valuable asset since they are considered to be able to better manage the interactions with them than their "Swedish" colleagues.

The private security company studied for this article was smaller than the county police authority, and it was not divided into different sections or divisions assigned their own kinds of policing tasks, patrolling areas, or types of criminality. The organizational ethnic matching relied on by the company was rather a strategy used to determine which company employees were sent out on which kinds of security assignments and on behalf of which customers. The staffing of each patrolling assignment was planned thoroughly with the aim of most effectively managing the reactions and impressions of the public expected to be encountered on the street, in order to facilitate the delivery of security services on the ground. These decisions were made based on what was known about the neighbourhood or the area in which the work was to be carried out (the city centre or a suburb), who the purchaser of the services was, what type of event, occasion, or function it was that was perhaps involved, and what kinds of individuals or groups of people were expected to be encountered on the assignment. If the assignment was at a hip hop concert in one of the suburbs, for example, it would be staffed by "dark-skinned security officers", as one company employee in charge of planning and staffing security missions described it (while officers with a lighter skin colour would be sent to a rock concert in the city centre). This was done to ensure that the employees to carry out the work on site would not correspond to the public's stereotypical image of "the security officer" as a "big blond guy with an attitude", an image seen as tainting the business and hampering the work of individual officers on the streets. During particularly turbulent periods in the city's ethnically and socio-economically segregated suburbs, the company had also begun to rely on organizational ethnic matching through what it referred to as "double staffing", which involved security personnel working in pairs composed of, as one security officer described it, "a mixture" of staff, "with one fair-skinned and one dark-skinned" security officer going on the assignment together (Hansen Löfstrand, 2013b).

Organizational ethnic matching, or attempts to create favourable work conditions by planning and staffing particular assignments so that they ensured a diversity of appearances and backgrounds among the officers sent to the street, was also practiced by the county police authority studied. Units engaged in covert policing selected the personnel for the assignments based on the nature of the operation in question, matching the officers to the perceived character and type of the area, neighbourhood, place, or social situation involved. Assignments were staffed and planned so that the personnel to carry them out would not correspond to the stereotypical image of police officers as distinctly "Swedish-looking" and uniformed. A common opinion among the interviewed police employees was that certain of their police's tasks and assignments required officers looking or appearing as opolisiära ("non-police-like") as possible. As one police officer reported during his interview, there was a dark-skinned co-worker of his who was frequently selected for undercover policing assignments at rave parties "because he didn't look like a police officer"; he "was picked because he was so dark." Police officers with that kind of "foreign appearance" were assumed to blend in more readily with the people expected to be encountered at the scene or location. Some work assignments, such as surveillance operations preceding planned drug raids and crackdowns in some of the city's immigrantdominated suburbs, were seen as being more efficiently carried out when handled by police officers who were opolisiära in their appearance, such as women officers or officers with "non-Swedish" or generally "foreign" looks. ${ }^{2}$ Only they, the interviewed police officers opined, were able to move around relatively freely in the ethnically and socio-economically segregated urban areas where the operations were carried out, not having their presence there stand out and become questioned. For this reason, the officers explained, they were commonly selected as "the first scouts", as those sent out first at the very outset of a surveillance and sting operation, since "they are the best suited for this job".

\subsection{Situational Ethnic Matching}

Situational ethnic matching, as we use the term in this article, was used by the policing agents in their particular and concrete interactions on the street. It involved situated activities and interactions where the police or security officers for strategic reasons omitted to specifically allude to their identity as policing agents, drawing on and performing ethnicity to avoid attracting attention to it. Situational ethnic matching was thus attempted using the technique of impression manage-

\footnotetext{
${ }^{2}$ As this indicates, not only ethnic minority representatives but also women were seen as highly valuable and useful to the organization. The same held for the private security company in this study. In this article, however, we limit our consideration of diversity to the issue of ethnicity. Both public and private policing organizations in Sweden have succeeded in hiring women better than they have ethnic minorities: 31 per cent of the all the police officers and 28 per cent of the private security officers working in the country are women, while, as already mentioned, only 3 per cent of all the country's police officers and 13 per cent of its private security officers are foreign-born (Statistics Sweden, 2012a).
} 
ment (Goffman, 1959), consisting of a particular performance of ethnicity to help them better manage their counterparties' impressions. This entailed drawing on symbolic resourses such as similarity or closeness of appearance (skin colour), mother tongue, style/bodily conduct, and emotive expressions (cf. Hansen Löfstrand, 2013a, 2013b). When practicing situational ethnic matching, the policing agents thus not only policed stereotypes, but also policed through stereotypes: they expressly drew upon and operationalized ethnicized stereotypes. Situational ethnic matching was mainly utilized towards two main ends: either to control situated actions in direct face-to-face interactions with individuals or groups encountered on assignments, through the use of soft rather than coercive powers, or to pass as a civilian, which required policing agents not to wear a uniform.

\subsubsection{Policing through Ethnic Stereotypes to Control Situated Actions}

In the county police authority and the private security company included in this study, situational ethnic matching in the form of policing through ethnic stereotypes tended to be used in particular socio-economic contexts: in the socio-economically and ethnically segregated suburbs of the city. An image of "threatening youths' in the dangerous suburbs" (Sernhede, 2006, p. 102) seems to be imprinted in the consciousness of many Swedes, stamping also the discursive environment in which both public police officers and security company operatives move. Drawing on the work of Waquant (e.g., Waquant, 2007; also Sernhede, 2009), this image can be seen as a product of processes of territorial stigmatization, denoting a general tendency to criminalize the socio-economic problems of marginalized populations. (This phenomenon is familiar in Sweden as well: see, e.g., Forkby \& Liljeholm Hansson, 2011; Hansen Löfstrand, 2013b; Sernhede, 2006, 2009; Uhnoo, 2013). Indeed, policing efforts overall have been observed to have a tendency to grow spatially focused, with policing through ethnic matching becoming taken up as an option and applied in the case of certain areas or spaces in the urban landscape only (Fyfe, 1991; Lowman, 1986).

When the police and private security officers studied for this article were asked about why, in their opinion, ethnic diversity of policing staff was worth pursuing, and in exactly which ways they thought it was beneficial to their work, they almost always referred to "the dangerous suburbs" in their responses. According to them, it facilitated their work in those suburbs, by helping them to avoid accusations of discrimination, calm down situations, and manage antagonistic and/or resentful emotions from the public. For all these reasons, they explained, police and security officers with "non-Swedish looks" were ideal for assignments involv- ing, in particular, suburban immigrant youths: they could make productive use of the perceived social distance between "foreigners" and the controlling bodies representing the country's rule-of-law institutions like the police and private security actors. If, for example, police officers differed in their appearance and manners from the stereotypical "white" police officers and were instead perceived of as "fellow foreigners", the explanation went, they had an opportunity to connect with immigrants, and immigrant youth in especial, in a positive way. One of the police officers in this study described how, when police officers with a "non-Swedish" appearance like him arrived in the suburbs, they were more often met with a degree of personal acceptance and trust, and perhaps even interest, compared to how it would have been had the officers on assignment been his ethnically Swedish-looking collegues.

The interviewed police officers from minority backgrounds, however, also described a pressure to live up to their role as representatives of the Swedish police before the youngsters they met on the streets. Very often, this had to do with a simultaneous need they felt to act as a role model for the latter, owing to their shared social status and ethnic background. Also one of the security officers in this study pointed out how "you're supposed to act as a role model for the suburban kids". For one thing, this meant encouraging the young men encountered on duty to think along the lines of "If he can do it, so can we", by giving an impression that they both shared some basic experiences as "immigrants". Responding to a question about the exact respects in which he considered himself as representing a role model, this security officer explained that in the Swedish society in general, being "an immigrant" was associated with criminality and a certain style of manners (acting like one who "owned the streets"), and when he, as a security officer coming himself from an immigrant background, went out into the suburbs to interact with young men, he became a role model for these as they believed him to share their experiences. One public police officer, for his part, considered that, since suburban youths from minority backgrounds are often subjected to stop and search, "many of them really believe the police to have prejudices [against them]", and that it was therefore important for them to "see foreigners working within the police department".

In the interviews with police and security officers, many examples were brought up of how accusations of discrimination and racism coming from juveniles in the suburbs were managed with the help of situational ethnic matching. One way for police officers to avoid accusations of discrimination and racism altogether, and manage such accusations when they nevertheless did occur, was to make use of situational ethnic matching by performing the role of "the immigrant police". More than one interviewed police officer claimed that 
when some among them looked sufficiently "nonSwedish", it was often enough that these officers simply got out of their patrol car for a situation to calm down. Sometimes they could also go one step further and address those gathering on the scene in their native tongue. One security officer, hailing from the former Yugoslavia, told that when being accused, or expecting to soon be accused, of ethnic discrimination, "I play the ace up my sleeve: I start talking in Bosnian", thus appealing to (presumed) similarities between himself and his audience at the site. This, the security officer claimed, often took the sting out of the accusations.

Situational ethnic matching-policing through stereotypes-thus appeared to offer a means for public police and private security officers to increase the chances that the members of the public otherwise most likely to show resentful attitudes towards policing agents will co-operate and view the actions of the policing agents as legitimate; it was, in other words, an effective tool for them with which to manage reputation and resent. For security officers of ethnic Swedish origin, while they all agreed that it was "a good idea to talk to the kids", it was, in contrast, very often "difficult to talk to the immigrant youth", because "all they say back is 'You are only talking to us because you think that we will do something'". As one of these officers reported, his co-worker who came from a non-Swedish ethnic background was met entirely differently in these situations, becoming addressed as "a brother right away" and possibly greeted with "Damn, how cool, you have a baton?" or something similar. His own chances of succeeding in his work this security officer felt to be "much bigger when dealing with middle-class brats in the wealthy suburbs." The strategy of situational ethnic matching, as a tool the officers used to gain control over situated actions by claiming likeness in terms of a shared "foreignness", could, however, also sometimes fail to produce this intended effect (cf. Hansen Löfstrand, 2013a; Uhnoo \& Peterson, 2011).

\subsubsection{Policing through Ethnic Stereotypes to Pass as a Civilian}

At other times, situational ethnic matching in the form of policing through stereotypes, or the policing agents' efforts to draw upon and perform ethnicity by claiming likeness to their interlocutors in terms of a shared ethnic background, was instead resorted to purposefully conceal, or at least not deliberately bring to the other persons' notice, one's identity and status as a police or security officer. In police work, this type of policing was most commonly practiced in connection with operations falling under covert policing activity: during them, ethnicity was performed by police officers to produce the appearance of being a civilian or, at any rate, to create an as non-police-like impression of oneself as possible. According to one interviewed police officer, those in the departmental workforce who were "foreign" and had "a foreign name and perhaps a foreign appearance" were the ones best suited for surveillance and reconnaissance tasks, involving as these often did engaging in activities in ethnic minority-dominated areas:

And then I'm a bit darker [than my co-workers], too, which is an advantage when you have to go out on a scouting mission...The archetypical image of a policeman working under cover in this country is that it's an ethnically Swedish male, aged about 30 to 35-but in me you can at least see some "Eastern" influence, if you wish...So for me it's easier to blend in, for example, in the suburbs, and mingle with people in those types of environments. It tends to take them a bit longer before they start suspecting me for being a police officer, if you compare it to a situation where one of my blondhaired co-workers goes into those places.

In other words, when police officers practiced policing through stereotypes in covert policing, this was by taking advantage of what they took to be stereotypical notions of themselves as held by the public: that those exercising control in society, be they police or security officers, were all ethnically "Swedish". What was then concealed or downplayed during covert policing operations was this "Swedishness" of the officer on the street. In contrast to situations where police and security officers had to actively engage in interaction with young people in the city's suburbs, this type of situational ethnic matching did not in the main entail appeals to ethnic "likeness" in direct face-to-face interactions to minimize resistance, confrontation, and the need for applying coercive control measures. Rather, in general, it involved actively performing and staging a "foreign" ethnicity in order to better blend in with certain social environments, without engaging in direct interactions where one's identity might become questioned. While "foreign" looks were the main resource or asset police and security officers could draw upon in these connections, the policing through stereotypes they practiced to hide their identity as policing agents also called for an ability to convincingly move around and act as someone part and parcel of the social environment in which the policing operation was unfolding.

The interviewed minority police officers frequently brought up the advantage they had over their "Swedish-looking" co-workers in these regards and how effortless and "natural" it was for them to partake in covert police operations in the city's ethnically nonSwedish suburbs (see also Loftus, Goold, \& Macgiollabhui, 2014). In this same vein, one private security officer coming from an ethnic minority background spoke about how he, personally, was never afraid of going in- 
to the city's ethnic minority-dominated suburbs and neighbourhoods wearing plainclothes, while entering such areas in a security officer's uniform made the situation altogether different: then one represented the Swedish rule-of-law institutions and was met accordingly. When working in the ethnic-minority areas and neighbourhoods, it was beneficial to have a "nonSwedish" background and not wear a uniform, and thus, when contracted to carry out crime prevention and safety work in the city's suburbs, the security company in this study sent its employees out into the streets wearing a uniform quite different from their usual one: a T-shirt in bright colors.

A police officer, coming from a Finnish background-but with a "Swedish" appearance (white skin, blonde hair)-described a situation unfolding in a marketplace in an immigrant-heavy suburb in which he, in the absence of other alternatives, found himself having to enact the role of a "Swedish criminal":

I was about to do some recce over there, like we usually do in preparation for certain types of operations, and I took a look around me and I was, like, "Jesus Christ!" Nothing but immigrants out there, basically...So I thought, "How the fuck" - sorry"am I going to solve this situation?" Luckily, it was warm outside, and I've got some tattoos here and there, so I took off my shirt and walked around out there having nothing but my shorts on me...It was the only way for me to be able to do any work out there. An incredible place.

To be able blend in with his particular social environment, the officer concealed his identity as a policing agent by removing his shirt to show off his tattooed upper body, acting in a way that, he expected, would in that environment attract no one's attention to what he took to be his stereotypical "Swedish criminal" appearance. In doing so, he drew on his knowledge of the stereotype that "Swedishness" in a policing context, as a characteristic of a policing agent, not only implied being white-skinned and blond-haired, but also meant acting and behaving in the manner of a good and respectable, law-abiding citizen of the country.

A comparable situation was described by one of the interviewed security officers coming from an ethnicminority background. One night, when busy driving from one site to another, he suddenly had to respond to a burglary alarm. Arriving at the scene and preparing to board up the broken window he found in a building there, a few men-"Serbs," according to the officershowed up and started yelling, "There he is, the bastard; get him!" Realizing he was in danger, the security officer, to borrow his own words, "enacted the crazy Yugoslavian", or, as he phrased it on another occasion, "went for the crazy-Yugoslav style". In this case, this meant talking loudly (in Serbo-Croatian) and behaving "cockily", using the body language and gestures of someone who "owned the streets", was at home in the neighbourhood, and demanded respect. The security officer yelled back to the men, "What the fuck do you want!", causing them to eventually back off, startled by his attitude. This, the security officer concluded, was because they realized that "Hey, he's one of us". He then went on to elaborate that, in doing so, his addressees assumed that he, too, was a fellow immigrant with brushes with the law at some point in his life:

You yourself don't have to have been a crook, but, really, what you do is you take advantage of people's prejudices. This is where "the crazy-Yugoslav" thing comes in: it's an enactment, a performance that I can use to my advantage; but of course they don't know that.

In order to downplay his status as a security officer and a representative of the Swedish rule-of-law institutions (clearly visible through his uniform), he enacted a performance as a stereotypical "Yugoslav crook", a not only ethnicized but also criminalized stereotype. In general, the purpose of this type of situational ethnic matching was to pass as a civilian person able to move around in a particular social environment without having one's presence become subject to questioning. If one's presence failed to go unnoticed, when one felt oneself to probably be in danger, or if one's cover risked being blown, additional measures became necessary and were made use of. On such occasions, not only ethnicized but also criminalized stereotypes were performed. All in all, these performances of ethnicity, as strategies of situational ethnic matching, were all premissed on the reproduction of the stereotypical image of "Swedes" as people who are white, blondehaired, law-abiding, and a little "square" in the behaviour, and of "foreigners" as individuals who are nonwhite, dark-haired, and badly-behaving "crooks".

\section{Diversity Policing and the Policing of Diversity: Inclusionary Rationale and Exclusionary Practices}

Our main objective has been to contribute to an improved conceptual understanding of the strategic use of ethnicity-or ethnicized stereotypes-in policing. Two distinct types of discourses and ways of "doing ethnicity" emerged as characteristic of the Swedish policing organizations studied. These we termed as 'diversity policing' and the 'policing of diversity'.

In the official discourse in Sweden, diversity policing, or the efforts by the police and security service operators to recruit and retain an ethnically diverse workforce, has been presented as an inclusive measure, with diversity typically framed as indicative of the organization's sense of social responsibility. This holds for both the public and private sector policing actors. 
More specifically, the proposal has been that diversity policing improves the policing actors' ability to mirror the ethnic heterogeneity of the population they serve, seen as critical for the public legitimacy of their purposes and actions in a democratic society.

Within the more unofficial discourse on ethnic diversity, one we have above linked to the strategy of policing diversity, workplace diversity was understood to refer to a workforce composition that mirrors the presence of "foreign elements" in society, with "foreigners" depicted as overrepresented among the "criminals" in the country. According to the logic of this second discourse, an ethnically diverse workforce is strategically necessary for the organization's operational ability and effectiveness. As our examination indicates, it was this latter, more unofficial discourse that provided the dominant norms for accepted thinking among the policing agents in this study, functioning as a model for them for interpreting, understanding, and also acting in their concrete work situations.

In discussing these two discourses and policing practices, we have highlighted the disjuncture that prevails between the widely accepted rationalities for diversity recruitment (diversity policing) and the realities for effective deployment of an ethnically diverse workforce at the street level (policing diversity). Paradoxically, while diversity policing is based on an inclusive rationale, our investigation of the strategic use of ethnic diversity among policing personnel shows the resulting policing practices to be exclusionary in their consequences. The achievement of diversity in hiring, ironically, facilitates ethnic matching, which in turn helps to perpetuate stereotypical thinking about Swedish "others".

Using the term 'organizational ethnic matching', we considered the practice of planning and staffing entire sections of a policing organization, or particular work tasks and assignments, in such a way as to ensure ethnic diversity in the staff dedicated to these. Organizational ethnic matching provided the policing actors studied with a tool enabling the strategic use of "Swedishness" and "foreignness" by their employees when carrying out their work tasks on the street. To address the particular kind of interactions involved when public police and private security officers for strategic purposes avoided calling attention to their status as policing agents, we employed the term 'situational ethnic matching'. In these interactions, the policing agents instead thematized and performed ethnicity, claiming likeness between themselves and their interlocutors in terms of a shared "foreignness". Policing through stereotypes in these cases involved drawing on symbolic resources such as physical appearance (like skin colour, colour of hair and eyes, and general physical appearance), mother tongue, behavioural style/bodily conduct, and emotive expressions. This strategy relied on stereotypical images, held by the public and the polic- ing agents alike, that depicted certain groups in society, namely "foreigners" (those with "dark" or otherwise "non-Swedish" features), as being particularly crime prone and residing in specific areas and social environments, in especial the ethnically and socioeconomically segregated major-city suburbs.

In Sweden, the term 'race' is only rarely if ever (publicly) used by those representing the country's government and rule-of-law institutions and those taking part in public debates. In its stead, the terminology of 'ethnicity', strongly associated with "foreign immigrant cultures" (Ålund, 1999, p. 107), and 'culture' is heavily favoured. In the discourses on ethnic diversity within the two policing organizations studied, the meaning of 'ethnicity', however, changed, with the term coming to be defined as denoting a certain kind of skin colour, general physical appearance, behaviour, language use, and language proficiency. This finding is in line with the tendency, noted in the Swedish context by Ålund (1999, p. 108), of notions such as 'ethnicity' and 'culture' to function as a smokescreen, as a means by which social inequalities, segregation, and instances of racialization are covered up. As a strategy, policing through stereotypes by our study participants relied on, and in turn reproduced, existing patterns of inequalities in society, a society in which being "Swedish" means being "white" (a blond, well-behaving, and lawabiding good citizen) while being "foreign" means being "dark" (dark-featured, badly behaving, and lawdespising if not outright criminal).

Both the public police and private security officers included in this study frequently referred to the socioeconomically and ethnically segregated suburbs in which they operated as high-crime environments that at least potentially were "dangerous". This image can be seen as a product of processes of territorial stigmatization, denoting a general tendency to criminalize the socio-economic problems of marginalized populations (e.g., Waquant, 2007; see also Sernhede, 2009). While ethnic minority groups indeed are overrepresented in official crime statistics in Sweden, most of this imbalance can, as suggested by previous research, be explained by indicators of socio-economic resources and neighbourhood segregation during childhood, showing this overrepresentation to be "in fact to a large extent economic and social inequality in disguise" (Hällsten, Szulkin, \& Sarnecki, 2013, p. 469).

As a strategy, the practice of policing through stereotypes can thus be said to both rely on and reproduce existing patterns of inequality in society. While there are practical considerations that limit the range of possible recommendations that could be made for policing practice based on this observation (can policing actors be asked to forgo a proven tool for public safety maintenance in the interest of achieving the [elusive] goal of stereotype change/eradication? etc.), it is nevertheless worth reflecting on its implications. A 
question for future research is whether the two discourses on ethnic diversity-diversity policing and policing diversity-run parallel to, and mirror, a racialized class-based hierarchy within policing organizations. Although not much research exists as yet even on the career paths of ethnic minority police officers (see, e.g., Fielding, 1999), previous studies nevertheless suggest such hierarchies to be at least potentially common across countries (e.g., Singh \& Kempa, 2007; van Ewijk, 2011). Although it seemed evident such hierarchies existed also in the two policing organizations studied for this article, it was not possible to empirical verify the accuracy of this impression or the possible existence of such hierarchies in other policing organizations in Sweden. Future studies should, therefore, be conducted to examine whether there indeed might be two broad cultures sustaining their own, different discourses in policing contexts. To the extent that this may turn out to be so, it would then also be pertinent to ask whether any official, higher-level discourse stressing the need to recruit and retain an ethnically diverse workforce might be promoted and reproduced by superior, "native" ("white"), and well-paid managements, while a more unofficial, lower-level discourse and its attendant strategy of policing through stereotypes to control and, sometimes, survey specific parts of the public ("foreigners") would then be enacted and reproduced by subordinate ethnic-minority officers. In such cases, ethnic-minority officers, through their use of situational ethnic matching, would, paradoxically, themselves be contributing to exclusionary practices towards groups already marginalized in society, thereby helping to perpetuate existing patterns of inequality and subordination. Instead of producing its intended results (substantive legitimacy acquired through more fair and just treatment of certain parts of the public), the policing strategy of situational ethnic matching would then only be able to serve as a means by which to repair and maintain mere symbolic legitimacy for policing actions and operations.

\section{Acknowledgements}

Research for this article was made possible by a research grant from the Swedish Research Council for Health, Working Life and Welfare (grant number 20090011) 'Policing Ethnicity in a Diversified Sweden', and a research grant from the Swedish Research Council (grant number 421-2012-417) 'Organizational legitimacy in quasi-markets: the provision of housing for the homeless and manned security services'. Furthermore, we wish to thank the three anonymous reviewers for their helpful comments.

\section{Conflict of Interests}

The authors declare no conflict of interests.

\section{References}

Ålund, A. (1999). Ethnicity, multiculturalism and the problem of culture. European Societies, 1(1), 105116.

Antonopoulos, G. A. (2003). Ethnic and racial minorities and the police: A review of the literature. The Police Journal, 76(3), 222-245.

Bayley, D. H., \& Shearing, C. (2001). The New Structure of Policing: Description, Conceptualization and Research Agenda. Washington, DC: National Institute of Justice.

Bowling, B., \& Phillips, C. (2007). Disproportionate and discriminatory: Reviewing the evidence on police stop and search. The Modern Law Review, 70(6), 936-961.

Button, M. (2002). Private Policing. Cullompton, UK: Willan.

Crawford, A. (2008). Plural Policing in the UK: Policing beyond the Police. In T. Newburn (Ed.), Handbook of Policing (2nd ed., pp. 147-181). Cullompton, UK: Willan.

Crawford, A., \& Lister, S. (2006). Additional security patrols in residential areas: Notes from the marketplace. Policing and Society, 16(2), 164-188.

de los Reyes, P. (2000). Diversity at work: Paradoxes, possibilities, and problems in the Swedish discourse on diversity. Economic and Industrial Democracy, 21(2), 253-266.

de los Reyes, P., \& Martinsson, L. (2005). Olikhetens paradigm-och några följdfrågor. In R. de los Reyes \& L. Martinsson (Eds.), Olikhetens paradigmintersektionella perspektiv på o(jäm)likhetsskapande (pp. 9-30). Lund: Studentlitteratur.

Feeley, M., \& Simon, J. (1992). The new penology: Notes on the emerging strategy of corrections and its implications. Criminology, 30(4), 449-474.

Fielding, N. (1999). Policing's dark secret: The career paths of ethnic minority officers. Sociological Research Online, 4(1), u38-u48. doi:10.5153/sro.237

Finstad L. (2000). Politiblikket. Oslo: Pax.

Forkby, T., \& Liljeholm Hansson, S. (2011). Kampen för att bli någon. Bilder av förorten och riskfyllda utvecklingsvägar i Göteborg. Gothenburg: FoU i Väst.

Fyfe, N. R. (1991). The police, space and society: The geography of policing. Progress in Human Geography, 15(3), 249-267.

Gabbidon, S. L. (2003). Racial profiling by store clerks and security personnel in retail establishments. Journal of Contemporary Criminal Justice, 19(3), 345-364.

Garland, D. (1996). The limits of the sovereign state: Strategies of crime control in contemporary society. The British Journal of Criminology, 36(4), 445-471.

Goffman, E. (1959). The Presentation of Self in Everyday Life. New York, NY: Doubleday Anchor.

Gunnmo, G. (2004). Mångfaldsarbete inom polisen-en 
lägesbeskrivning. Stockholm: Government Offices of Sweden/Ministry of Justice.

Hällsten, M., Szulkin, R., \& Sarnecki, J. (2013). Crime as a price of inequality? The gap in registered crime between childhood immigrants, children of immigrants and children of native Swedes. British Journal of Criminology, 53(3), 456-481.

Hallsworth, S. (2006). Racial targeting and social control: Looking behind the police. Critical Criminology, 14(3), 293-311.

Hansen Löfstrand, C. (2013a). När säkerhet blir en marknadsvara. Etnisk mångfald som resurs och problem för bevakningsföretag. In A. Peterson \& $\mathrm{M}$. Åkerström (Eds.), Den sorterande ordningsmakten. Studier av etnicitet och polisiär kontroll (pp. 225248). Malmö: Bokbox.

Hansen Löfstrand, C. (2013b). Private security policing by "ethnic matching" in Swedish suburbs: Avoiding and managing accusations of ethnic discrimination. Policing and Society. doi:10.1080/10439463.2013. 817996

Holmberg, L. (2003). Policing Stereotypes: A Qualitative Study of Police Work in Denmark. Glienicke: Galda + Wilch.

Hutchinson, S., \& O'Connor, D. (2005). Policing the new commons: Corporate security governance on a mass private property in Canada. Policing and Society, 15(2), 125-144.

Hydén, S., \& Lundberg, A. (2004). Inre utlänningskontroll i polisarbete. Mellan rättsstatsideal och effektivitet $i$ Schengens Sverige. Malmö: Malmö University Press.

Johnston, L. (1999). Private policing in context. European Journal on Criminal Policy and Research, 7(2), 175-196.

Johnston, L., \& Shearing, C. D. (2003). Governing Security: Explorations in Policing and Justice. New York, NY: Routledge.

Jones, M., \& Williams, M. L. (2013). Twenty years on: Lesbian, gay and bisexual police officers' experiences of workplace discrimination in England and Wales. Policing and Society. doi:10.1080/10439463. 2013.817998

Kempa, M., \& Singh, A.-M. (2008). Private security, political economy and the policing of race: Probing global hypothesis through the case of South Africa. Theoretical Criminology, 12(3), 333-354.

Kempa, M., Carrier, R., Wood, J., \& Shearing, C. (1999). Reflections on the evolving concept of 'private policing'. European Journal on Criminal Policy and Research, 7(2), 197-223.

Lander, I. (2013). Obstacles for changes within the (Swedish) police force: Professional motivations, homosociality, and ordering practices. Journal of Scandinavian Studies in Criminology and Crime Prevention, 14(1), 43-61.

Loader, I. (2000). Plural policing and democratic gov- ernance. Social and Legal Studies, 9(3), 323-345.

Loftus, B., Goold, B., \& Macgiollabhui, S. (2014). Covert policing: An erudite working culture. Manuscript draft.

Lowman, J. (1986). Conceptual issues in the geography of crime: Toward a geography of social control. Annals of the Association of American Geographers, 76(1), 81-94.

Mattson, T. (2005). Diskrimineringens andra ansiktesvenskhet och 'det vita västerländska'. In P. de los Reyes \& M. Kamali (Eds), Bortom Vi och Dom. Teoretiska reflektioner om makt, integration och strukturell diskriminering (Swedish Government Official Reports SOU 2005:41, pp. 139-157). Stockholm: Fritzes.

McCahill, M. (2002). The Surveillance Web: The Rise of Visual Surveillance in an English City. Cullompton, UK: Willan.

O’Dougherty, M. (2006). Public relations, private security: Managing youth and race at the Mall of America. Environment and Planning D: Society and Space, 24(1), 131-154.

Pettersson, T. (2013). Belonging and unbelonging in encounters between young males and police officers: The use of masculinity and ethnicity/race. Critical Criminology, 21(4), 417-430.

Rigakos, G. S. (2002). The New Parapolice: Risk Markets and Commodified Social Control. Toronto: Toronto University Press.

Rose, N. (2000). Government and control. British Journal of Criminology, 40(2), 321-339.

Rowe, M. (2002). Policing diversity: Themes and concerns from the recent British experience. Policing Quarterly, 5(4), 424-446.

Sernhede, O. (2006). Förortens "hotfulla unga män." Andrefieringens geografi och behovet av alternativ till stigmatisering och kriminalisering. In M. Kamali (Ed.), Den segregerande integrationen. Om social sammanhållning och dess hinder (Swedish Government Official Reports SOU 2006:73, pp. 91-123). Stocholm, Fritzes.

Sernhede, O. (2009).Territoriell stigmatisering, ungas informella lärande och skolan i det postindustriella samhället. Utbildning \& Demokrati, 18(1), 7-32.

Singh, A.-M., \& Kempa, M. (2007). Reflections on the study of private policing cultures: Early leads and key themes. In M. O'Neill, M. Marks, \& A.-M. Singh (Eds.), Police Occupational Culture: New Debates and Directions (Sociology of Crime, Law and Deviance Vol. 8, pp. 297-320). London: Elsevier/JAI.

Sollund, R. (2006). Racialisation in police stop and search practice: The Norwegian case. Critical Criminology, 14(3), 265-292.

Statistics Sweden. (2012a). Occupational statistics by employed persons aged 16-64 by region of birth and sex. Stockholm: Database Statistics Sweden.

Statistics Sweden. (2012b). Compilation of data on 
population per city area and foreign/native background. Stockholm: Database Statistics Sweden.

Statistics Sweden. (2013). Population statistics by age and foreign/native background. Stockholm: Database Statistics Sweden.

Stenning, P. (2009). Governance and accountability in a plural policing environment: The story so far. Policing, 3(1), 22-33.

The Swedish National Police Board (2010). Diversity: The Swedish Police's national policy and plan for diversity and equality 2010-2012: National policy and action plan. Stockholm: Swedish National Police Board.

The Swedish National Police Board (2014). Annual Report of the Police Authority 2013. Stockholm: The Swedish National Police Board.

Thumala, A., Goold, B., \& Loader, I. (2011). A tainted trade? Moral ambivalence and legitimation work in the private security industry. British Journal of Sociology, 62(2), 283-303.

Uhnoo, S. (2013). Within "the tin bubble": The police and ethnic minorities in Sweden. Policing and Society. doi:10.1080/10439463.2013.817995

Uhnoo, S., \& Peterson, A. (2011). Utvärdering om diskriminering, trakasserier och särbehandling av anställda med utländsk bakgrund inom polismyndigheten i Västra Götaland. Gothenburg: University of Gothenburg and Västra Götaland County Police.

van Ewijk, A. R. (2011). Diversity within police forces in Europe: A case for the comprehensive view. Policing, 6(1), 76-92.

Wakefield, A. (2003). Selling Security: The Private Policing of Public Space. Devon, UK: Willan.

Waquant, L. (2007). Urban Outcasts: A Comparative Sociology of Advanced Marginality. Cambridge, UK: Polity Press.

Ward, G. K. (2006). Race and the justice workforce: Toward a system perspective. In R. D. Peterson, L. J. Krivo, \& J. Hagan (Eds.), The Many Colors of Crime: Inequalities of Race, Ethnicity, and Crime in America. New York, NY: New York University Press.

Wästerfors, D., \& Burcar, V. (2014). Safety Work with an Ethnic Slant. Social Inclusion, 2(3), 88-101.

Werner, J. (2014). Blond och blåögd. Vithet, svenskhet och visuell kultur (Skiascope No. 6). Gothenburg: The Gothenburg Museum of Art.

Williams, C. A. (2008). Constables for hire: The history of private "public" policing in the UK. Policing and Society, 18(2), 190-205.

Young, J. (1994). Policing the Streets: Stops and Search in North London. London, UK: Centre for Criminology, Middlesex University.

Zedner, L. (2003). Too much security? International Journal of the Sociology of Law, 31(3), 155-184.

\section{About the Authors}

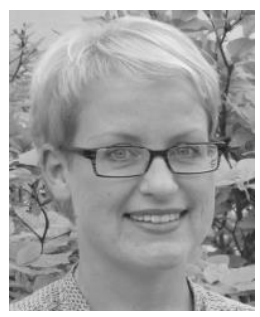

\section{Dr. Cecilia Hansen Löfstrand}

Cecilia Hansen Löfstrand is Associate Professor of Sociology and Senior Lecturer at the Department of Sociology and Work Science, University of Gothenburg, where she received her PhD in Sociology in 2005. She has researched the politics of homelessness, crime victim support and the private security industry. Currently, she conducts research within her project 'Organizational legitimacy in quasimarkets: the provision of housing for the homeless and manned security services'. She is also a member of the research programme "Policing Ethnicity in a Diversified Sweden".

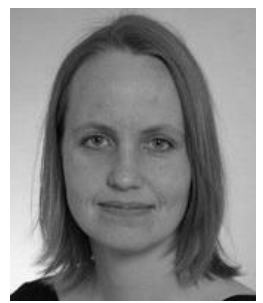

\section{Dr. Sara Uhnoo}

Sara Uhnoo is Senior Lecturer and researcher at the Department of Sociology and Work Science, University of Gothenburg. She received her PhD in Sociology from the University of Gothenburg in 2011. Her main areas of research include youth talk about violence, firesetting by children and juveniles, and diversity work within the Police. She is a member of the research programme "Policing Ethnicity in a Diversified Sweden", financed by the Swedish Council for Working Life and Social Research (headed by Professor Abby Peterson and Professor Malin Åkerström). 